\title{
PENGARUH TRANSFORMASI SOSIAL PADA PERLINDUNGAN HUKUM PROFESI KEDOKTERAN TERHADAP MALAPRAKTIK MEDIK
}

\author{
Andi Syarifuddin \\ Mahasiswa Program Doktor Ilmu Hukum Pascasarajana UMI Makassar \\ email : Andi.Syarifuddin@gmail.com
}

\begin{abstract}
The influence of social transformation in the relationship between doctor and patient medical in health care, which is unchanged in terms of both the development of science and medical technology as well as in terms of increasingly sophisticated medical equipment. Changes in medicine in adjusting to the development or transformation of science that took place globally, which is more focused on the actualization of resource quality and the perpetrators of medical and actualization of the aspects of the instrument of facilities and infrastructure to support the service in the medical field. In an effort to build a balance or equality impact on the quality of medical services more quality, berkepastian and fair and expediency, legal counseling needs to be done simultaneously to socializing the various aspects of medical law against citizens as the most important stakeholders in the world of medical services.
\end{abstract}

Keywords: legal protection, doctors, Malpractice.

\begin{abstract}
Abstrak
Pengaruh transformasi sosial dalam hubungan antara dokter dan pasien dalam perawatan kesehatan, yang tidak berubah dalam hal pengembangan ilmu pengetahuan dan teknologi medis serta dalam hal peralatan medis yang semakin canggih. Perubahan ilmu kedokteran dalam menyesuaikan diri dengan perkembangan atau transformasi ilmu yang terjadi secara global, yang lebih fokus pada aktualisasi kualitas sumber daya dan pelaku medis dan aktualisasi aspek instrumen sarana dan prasarana untuk mendukung layanan di bidang medis. Dalam upaya membangun keseimbangan atau dampak kesetaraan pada kualitas layanan medis yang lebih berkualitas, berkepastian dan adil dan bijaksana, konseling hukum perlu dilakukan secara bersamaan untuk mensosialisasikan berbagai aspek hukum kedokteran terhadap warga negara sebagai pemangku kepentingan terpenting di dunia. layanan medis.
\end{abstract}

Kata kunci: Perlindungan Hukum; Dokter; Malpraktik;

\section{A. PENDAHULUAN}

Program pembangunan kesehatan di Indonesia ditujukan untuk meningkatkan kesadaran, kemauan, dan kemampuan hidup yang sehat bagi setiap orang, dalam rangka mewujudkan derajat kesehatan yang optimal sebagai salah satu unsur kesejahteraan umum

Vol. 20 No. 1 Mei 2018 
sebagaimana dimaksud dan ditegaskan dalam Pembukaan Undang-Undang Dasar Negara Republik Indonesia Tahun 1945.Kesehatan sebagai hak asasi manusia (HAM), harus diwujudkan dalam bentuk pemberian berbagai upaya kesehatan kepada seluruh masyarakat, melalui penyelenggaraan pembangunan kesehatan yang berkualitas dan terjangkau oleh masyarakat.

Penyelenggaraan praktik kedokteran yang merupakan salah satu bagian inti, dari berbagai kegiatan dalam penyelenggaraan upaya kesehatan harus dilakukan oleh dokter yang mengacuh pada standar kode etik, moral yang tinggi, dan keahlian sebagai profesi.Kebijakan pembangunan di bidang kesehatan yang semula berupa upaya penyembuhan penderita, secara berangsur-angsur berkembang ke arah kesatuan upaya pembangunan kesehatan masyarakat dengan peran serta masyarakat yang bersifat menyeluruh, terpadu dan berkesinambungan yang meliputi upaya peningkatan penyuluhan (promotif), upaya pencegahan (preventif), penyembuhan (kuratif), sangat penting dibanding upaya pemulihan (rehabilitatif). ${ }^{1}$ Berdasarkan upaya tersebut, maka setiap upaya untuk meningkatkan derajat kesehatan masyarakat tersebut dilaksanakan berdasarkan prinsip-prinsip non diskriminatif, partisipatif, perlindungan dan berkelanjutan.

Pada hakekatnya tujuan pembangunan kesehatan yang diselenggarakan oleh pemerintah, agar masyarakat mendapatkan hak-haknya atas dasar tolong-menolong.Hal ini sejalan dengan prinsip-prinsip dalam agama Islam, sebagaimana firman Allah dalam surah Al-Maidah ayat $2:^{2}$

Artinya: "Tolong-menolonglah dalam mengerjakan kebaikan dan taqwa jangan tolong-menolong dalam berbuat dosa kejahatan dan pelanggaran, dan bertaqwalah kepada Allah, sesungguhnya Allah sangat pedih siksaannya".

Hubungan hukum antara dokter dengan pasien merupakan hubungan pelayanan kesehatan (medical service), atau istilah lain tindakan medik antara health providern (pemberi layanan kesehatan) dengan health receiver (penerima layanan kesehatan).Bidang kedokteran yang pada awalnya berlangsung secara kekeluargaan, kini mulai dimasuki aneka persoalan hukum. Era sekarang dapat dirasakan bahwa kegiatan dokter dalam menyembuhkan pasien sering terhambat oleh sikap pasien atau keluarganya, yaitu kebiasaan menuntut secara hukum terhadap dokter jika pengobatanya dianggap kurang berhasil. ${ }^{3}$ Bahkan dokter sering diklaim telah melakukan perbuatan dengan istilah malpraktek yang merugikan pasien. Kebutuhan pasien dan dokter yang pada awalnya berjalan baik-baik saja, lambat laun seiring adanya gesekan dari luar hingga muncul suatu masalah, yang dapat bermuara sampai ke pengadilan. Karena itu, sangat di perlukan perlindungan hukum yang dapat menjadi payung, sehingga tercipta suasana damai aman dan nyaman pada kedua belah pihak.

Berbagai teori transformasi sosial yang berkembang dewasa ini, memengaruhi berbagai aspek di bidang kedokteran, tidak lepas dari perubahan sosial yang terus berlangsung. Berbagai aspek di bidang medis yang terus mengalami transformasi atau

1 Bahder Johan Nasution,2005,Hukum Kesehatan Pertanggungjawaban Dokter, PT. Rineka Cipta, Jakarta,hal 2-3

${ }^{2}$ Hasbi Asshiddiqi dkk, 1990,Al-Qur'an dan Terjemahannya, Depag RI, Jakarta, hal 156

3 Bambang Poernomo, 2005, Hukum Kesehatan, Yogyakarta: Program Pasca Sarjana Magister Manajemen Rumah Sakit UGM, hal 5-6

Vol. 20 No. 1 Mei 2018 
perubahan, antara lain berbagai peralatan alat kedokteran yang semakin canggih, racikanracikan obat yang semakin efektif, demikian pula dengan tingkat kesadaran masyarakat akan hak dan kewajiban mereka dibidang medis. Hal tersebut, ditandai dengan munculnya gugatan-gugatan terhadap dokter yang diduga melakukan perbuatan malpraktik. Dengan demikian transformasi sosial yang melanda dunia juga melanda dunia kedokteran dari segala aspek.

Tidak dapat dipungkiri bahwa fenomena malpraktik di Indonesia bukan menjadi hal yang tabu untuk diperbincangkan. Praktik kedokteran yang menyimpang dari standar prosedur kedokteran akan menimbulkan malpraktik, dan yang menariknya lagi kasus malpraktik selalu dialami oleh masyarakat golongan ekonomi menengah kebawah. Tidak seragamnya data malapraktik di Indonesia, karena setiap lembaga pendamping masyarakat selalu mempunyai daftar kasus yang berbeda-beda, bahkan lembaga Negara yang berwewenang, misalnya Kementerian Kesehatan, dan Lembaga organisasi kedokteran tidak memiliki data yang akurat.

Semakin banyaknya gugatan dari pasien, ternyata memberikan dampak yang negatif, yaitu adanya ketakutan dari dokter dalam memberikan upaya kesehatan kepada pasien. Dokter menjadi ragu-ragu dan takut, hal itu terungkap dalam kongres Perhimpunan Hukum Kesehatan Indonesia (PERHUKI) yang diadakan tanggal 24-25 Nopember 1985.Karena itu, dokter yang sudah mempunyai kelengkapan syarat administrasi untuk berpraktik, berhak memperoleh perlindungan hukum, agar merasa aman dalam menjalankan profesinya. ${ }^{4}$ Dampak lain, yang cukup mengkhawatirkan adalah dokter melakukan praktek pengobatan defensif, yaitu melakukan praktek kedokteran yang over standar maupun sub standar untuk menghindari resiko tuntutan, yang akhirnya akan merugikan masyarakat sendiri sebagai pengguna jasa dokter. ${ }^{5}$ Dengan demikian secara empirik, telah terjadi dampak dari transformasi sosial terhadap perlindungan hukum profesi dokter dalam melaksanakan tugas dan profesinya, khususnya dalam menghadapi tuntutan adanya kemungkinan malapraktik. Untuk itu, diperlukan pengkajian mendalam berkenaan dengan pengaruh transformasi sosialpada perlindungan hokum profesi kedokteran terhadap malpraktik medik.

\section{B. ANALISIS DAN PEMBAHASAN}

\section{Transformasi Sosial}

Dalam ilmu kedokteran, kata transformasi sosial sangat penting terutama dalam hubungan dengan perkembangan ilmu pengetahuan dan teknologi diera moderen ini, oleh sebab itu sangat perlu adanya keseragaman dalam memberikan pemahaman secara menyeluruh mengenai transformasi sosial di bidang medis. Transformasi sosial adalah segala sesuatu perubahan yang terjadi dalam hubungan sosial (social relation) atau perubahan-perubahan atas keseimbangan (equilibrium) hubungan sosial di bidang pelayanan kesehatan antara dokter dan pasien.

Transformasi sosial adalah gabungan dari dua kata 'transformasi' dan 'sosial'.

\footnotetext{
${ }^{4}$ Anny Isfandyarie, 2005, Malpraktek dan Resiko Medik Dalam Kajian Hukum Pidana, Penerbit Prestasi Pustaka, Jakarta,hal 6

${ }^{5}$ Safitri Hariyani,2005, Sengketa Medik, Alternatif Penyelesaian Perselisihan Antara Dokter dengan Pasien,Jakarta: PT. Diadit Media.hal 3
}

Vol. 20 No. 1 Mei 2018 
Transformasi dalam ensiklopedia umum merupakan istilah ilmu eksakta yang kemudian dimasukan ke dalam ilmu sosial dan humaniora, yang memiliki maksud perubahan bentuk dan secara lebih rinci memiliki arti perubahan fisik maupun nonfisik (bentuk, rupa, sifat, dan sebagainya). Sementara kata 'sosial' memiliki pengertian, segala sesuatu yang mengenai masyarakat, dan kedua, suka memperhatikan kepentingan umum (suka menolong, menderma dan sebagainya).

Dalam hubungannya dengan tranformasi sosial, semua ideologi atau filasafat sosial memiliki pertanyaan pokok yang sama, yaitu bagaimana mengubah masyarakat dari tatanan yang sekarang menuju tatanan yang ideal sesuai dengan ideologinya masing-masing. Teori-teori sosial yang muncul, memberikan gambaran empiris kondisi masyarakat saat ini, dan sekaligus tawaran perubahannya. Mengasumsikan semua ideologi yang memliki target tranfomatif, kecuali teori sosial yang hanya berkepentingan untuk ekspalanasi-ekspalanasi antropologis.

Upaya transformasi sosial dalam Islam merupakan perwujudan perintah dari yang abdi, bagaimana amar makruf diterjemahkan sebagai humanisasi dan emansipasi serta nahi mungkar sebagai liberasi mampu terlaksana dengan baik, dan karena kedua sisi (amar makruf dan nahi mungkar) tidak dapat dipisahkan dalam kerangka keimanan, maka keduanya haruslah dapat berjalan beriringan, Allah Berfirman dalam surah Ali Imran ayat 104: ${ }^{6}$

Artinya: "Dan hendaklah ada diantara kamu segolongan ummat yang menyeru kepada kebajikan, menyuruh kepada yang ma'ruf dan mencegah kepada yang munkar, merekah orang-orang yang beruntung".

Dalam setiap masyarakat dan dalam tahap historis apapun cita-cita untuk humanisasi, emansipasi, liberasi dan transendensi selalu akan menggerakkan transformasi Islam. Menurut M.Khaliq Salha, Transformasi sosial memiliki pengertian di antaranya; perubahan menyeluruh dalam bentuk, rupa, sifat, watak, dan sebagainya, dalam hubungan timbal balik sebagai individu-individu maupun kelompok-kelompok dalam masyarakat. ${ }^{7}$

Berdasar pada perbedaan orientasi formal, maka kemudian berkembang berbagai pendapat yang berbeda di antara sosiolog dalam melihat orientasi analisis, dan tema substantif perubahan sosial. Perbedaan-perbedaan itu, biasanya bersumber dari perbedaan asumsi dasar dalam melihat masyarakat. Misalnya, ada yang memandang masyarakat merupakan sesuatu yang life, dan karena itu pastilah berkembang dan kemudian berubah. Kajian utama perubahan sosial mestinya juga menyangkut keseluruhan aspek kehidupan masyarakat, atau harus meliputi semua fenomena sosial yang menjadi kajian sosiologi. Cara pandang demikian mengindikasikan bahwa perubahan sosial mengandung perubahan dalam tiga dimensi: struktural, kultural, dan interaksional. Jadi, orang baru bisa menyebut telah terjadi perubahan sosial, manakala telah dan sedang terjadi perubahan pada ketiga dimensi dimaksud,atau singkatnya perubahan sosial tidak lain merupakan perubahan dalam sistem sosial.

\footnotetext{
${ }^{6}$ Hasbi Asshiddiqi dkk, 1990, Al-Qur'an dan Terjemahannya, Depag RI, Jakarta, hal 93

${ }^{7}$ M.Khaliq Salha, 2014, Teori Perubahan Sosial hal.2
} 


\section{Hubungan Hukum Dokter Dengan Pasien}

Hubungan hukum antara dokter dengan pasien sebetulnya merupakan hubungan pelayanan kesehatan (medical service), atau istilah lain tindakan medik antara health provider(pemberi layanan kesehatan) dengan health receiver(penerima layanan kesehatan).

Perkembangan pola hubungan antara dokter dengan pasien atau lazim disebut dengan transaksi terapeutik ini, berkembang dari pasien hanya dianggap sebagai objek semata. Karena dokter dianggap paling tahu segala yang terbaik bagi pasien atau father know best, maka hubungan transaksi terapeutik ini berpola hubungan vertikal. Kemudian semakin lama hubungan antara dokter atau dokter gigi dengan pasien tersebut, bergeser dalam hubungan yang lebih seimbang, karena dokter dan pasien memiliki hak dan kewajiban masing-masing yang harus dipenuhi.Hubungan semacam ini, dikenal dengan transaksi terapeutik ${ }^{9}$. Mengenai hubungan hukum dokter dengan pasien, JP. Thiraoux ${ }^{10}$ memberikan 3 (tiga) pandangan mengenai hubungan tersebut, yaitu: a. Paternalistic, b. individualistic, c. reciprocal atau collegial.

Berdasarkan pada ketiga pola hubungan dokter atau dokter gigi dengan pasiennya tersebut, maka pandangan ketigalah yang akan terdapat dalam hubungan transaksi terapeutik tersebut. Karena kesamaan kedudukan hak dan kewajiban antara dokter atau dokter gigi dengan pasien, sehingga diharapkan tercipta kerjasama yang saling menguntungkan diantara kedua belah pihak.Dalam perkembangan mutakhir, hubungan jenis pola ketiga inilah yang dikembangkan dalam hubungan dokter dengan pasien, karena pasien menjadi subjek hukum bukan lagi sebagai objek hukum.

Selanjutnya mengenai hak dan kewajiban dokter dan pasien, dari sudut pandangan sosiologi-yuridis, maka seorang dokter atau dokter gigi yang melakukan hubungan medis atau transaksi terapeutik masing-masing mempunyai kedudukan dan peranan. Kedudukan merupakan wadah hak-hak dan kewajiban-kewajiban, sedangkan peranan merupakan pelaksanaan hak-hak dan kewajiban-kewajiban tersebut.Secara sederhana dapat dikatakan bahwa hak merupakan wewenang untuk berbuat atau tidak berbuat, sedangkan kewajiban adalah beban atau tugas yang harus dilaksanakan. Pada hakekatnya hak dan kewajiban merupakan pasangan, oleh karena dimana ada hak pasti ada kewajiban, dan begitu juga sebaliknya.Seseorang yang mempunyai hak pasti berkewajiban untuk tidak menyalahkan haknya, sedangkan kewajiban yang ada pada seseorang pasti disertai hak untuk tidak diganggu dalam melaksanakan tugasnya.Dahulu, kedudukan dokter atau dokter gigi dianggap lebih tinggi dari pasien, dan oleh karena itu peranannya juga dianggap lebih penting. Dengan perkembangan kehidupan dalam masyarakat, maka pola hubungan dokter atau dokter gigi dengan pasien mengalami perubahan bentuk.

Semakin banyaknya peraturan yang memberikan perlindungan hukum kepada pasien, sehingga pasien semakin mengetahui dan memahami hak-haknya dalam hubungannya dengan dokter.Demikian pula, tingkat kecerdasan masyarakat mengenai kesehatan semakin meningkat.Menurut Leenen ${ }^{11}$, bahwa manusia mempunyai 2 (dua)

\footnotetext{
${ }^{9}$ Syahrul Machmud, 2012, Penegakan Hukum dan Perlindungan Hukum Bagi Dokter yang diduga Melakukan Medikal Malapraktik, Karya Putra Darwati, Bandung, hal. 36

${ }^{10}$ Ibid

${ }^{11}$ Ibid hal 89
} 
macam hak asasi, yaitu hak asasi sosial dan hak asasi individual.Batas antara keduanyaagak kabur, sehingga diperlukan suatu landasan pemikiran yang berbeda.Hal tersebut, dikarenakan hak asasi individual mempunyai aspek sosial.Kedua katagori hak asasi tersebut, dalam kenyataannya mengungkapkan dimensi individual dan sosial dari keberadaan atau eksistensi sesuatu. Hak atas pelayanan kesehatan merupakan salah satu hak asasi sosial manusia.

\section{Malpraktik dan Tanggung Jawab Profesi Dokter}

Malpraktik merupakan istilah yang sangat umum sifatnya dan tidak selalu berkonotasi yuridis. Secara harfiah "mal" mempunyai arti "salah" sedangkan "praktek" mempunyai arti "pelaksanaan" atau "tindakan", sehingga malpraktek berarti "pelaksanaan atau tindakan yang salah". Meskipun arti harfiahnya demikian tetapi kebanyakan istilah tersebut, dipergunakan untuk menyatakan adanya tindakan yang salah dalam rangka pelaksanaan suatu profesi. Adapun definisi malapraktik medik, adalah kelalaian dari seseorang dokter untuk mempergunakan tingkat kepandaian dan ilmu pengetahuan dalam mengobati dan merawat pasien, yang lazim dipergunakan terhadap pasien atau orang yang terluka menurut ukuran dilingkungan yang sama.

J. Guwandi ${ }^{12}$ menyebutkan bahwa malpraktik adalah istilah yang mempunyai konotasi buruk, bersifat stigmatis, menyalahkan. Praktik buruk dari seseorang yang memegang suatu profesi dalam arti umum seperti dokter, ahli hukum, akuntan, dokter gigi, dokter hewan, dan sebagainya. Apabila ditujukan kepada profesi medik, maka akan disebut malpraktik medik.

Dalam kaitan dengan tanggung jawab dokter yang melakukan malpraktik, dapat terjadi dalam dua bentuk yaitu tanggungjawab dalam arti responsibility, adalah sikap moral untuk melaksanakan kewajibannya. Sedangkan tanggungjawab dalam arti liability, adalah sikap hukum untuk pertanggungjawaban pelanggaran atas kewajibannya atau pelangggaran atas hak pihak lain.

\section{Pengaruh transformasi sosial terhadap hubungan medik antara dokter dan pasien dalam pelayanan kesehatan}

Transformasi sosial memilki makna yang sangat besar terhadap berbagai aspek kehidupan manusia. Bahkan transformasi sosial menjadi sumber, sehingga terjadi suatu perubahan sosial pada berbagai aspek kehidupan di dalam masyarakat, termasuk aspek medis secara umum. Terjadinya perubahan sosial atau apa yang menjadi sumber dari suatu perubahan sosial, menurut Soejono Soekanto, bahwa terdapat beberapa faktor yang dapat menyebabkan terjadinya perubahan baik dalam ukuran yang paling kecil, yaitu perilaku kita ataupun dalam ukuran yang lebih luas yaitu struktur dan budaya masyarakat kita. Tetapi secara garis besar faktor-faktor tersebut dapat dibedakan sebagai sumber perubahan sosial yang berasal dari dalam

${ }^{12}$ Syahrul Mahmud, 2012, Penegakan huku dan perlindungan hukum bagi dokter yang diduga melakukan medical malprake, hal. 262. 
masyarakat atau internal (endogenous) dan dari luar masyarakat itu sendiri atau eksternal (exogenous).

Demikian halnya dengan aspek bidang medis, perubahan sosial membawa pengaruh yang besar terhadap perubahan yang terjadi dalam aspek pelayanan medis, yakni berpengaruh terhadap berbagai hal antara lain:

a. Hubungan medik secara umum;

b. Hubungan Hukum Dokter Dengan Pasien;

c. Hak dan Kewajiban Dokter dan Pasien;

d. Pelayanan Kesehatan.

Selanjutnya mengenai pengaruh perubahan sosial terhadap hubungan medik yang merupakan hubungan antara dokter dan pasien dalam ilmu kedokteran umumnya berlangsung sebagai hubungan biomedis.Pasien adalah setiap orang yang melakukan konsultasi masalah kesehatannya untuk memperoleh pelayanan kesehatan yang diperlukan, baik secara langsung maupun tidak langsung di Rumah Sakit. Pasien yang mengalami masalah kesehatan akan mendatangi dokter, atau rumah sakit untuk mendapatkan pelayanan kesehatan. Harapan pasien dengan pelayanan kesehatan yang diberikan, maka masalah kesehatan yang ia hadapi akan terselesaikan, atau singkatnya ia akan sembuh atau sehat kembali.

Berdasarkan hasil penelitian yang dilakukan menunjukkan bahwa dari 300 responden yang menyatakan, bahwa perubahan perkembangan ilmu pengetahuan dan teknologi pada bidang kedokteran mengalami perkembangan atau kemajuan searah dengan perubahan sosial sebanyak 225 (75,0\%) responden. Sedangkan 64 (21,3\%) responden berpendapat kurang berkembang, dan yang menyatakan tidak berkembang sebanyak $11(3,7 \%)$ responden. Fakta empirik ini, mengandung arti bahwa telah terjadi perubahan perkembangan ilmu pengetahuan dan teknologi pada bidang kedokteran, searah dengan perkembangan atau kemajuan dari perubahan sosial. Adapun aspek bidang kedokteran/medis yang mengalami perubahan antara lain, perkembangan pengetahuan para tenaga kesehatan, teknologi peralatan kesehatan, dan pemahaman masyarakat.

Demikian pula denganperlindungan hukum malpraktik medik bagi dokter dan pasien. Berdasarkan hasil penelitian diketahui bahwa dari 300 responden, yang menyatakan pelaksanaan perlindungan hukum terhadap dokter yang menjalankan profesi yang di duga melakukan malpraktik medik, sebanyak $104(34,7 \%)$ respondenberpendapat sudah terlindungi. Namun demikian, terdapat sebanyak $153(51,0 \%)$ responden yang menyatakan masih kurang terlindungi, sedangkan 43 (14,3\%) responden justru berpendapat tidak terlindungi. Kenyataan ini, dapat berarti bahwa pada umumnya responden memandang pelaksanaan perlindungan hukum terhadap dokter yang menjalankan profesi yang di duga melakukan malpraktik medik, kurang memperoleh perlindungan.

Selain itu, hasil penelitian ini juga menunjukkan bahwa dari 300 responden yang menyatakan tentang perlindungan hukum terhadap pasien yang di duga menjadi korban 
malpraktik medik, terdapat sebanyak $53(17,7 \%)$ responden berpendapat sudah memperoleh perlindungan hukum. Namun terdapat sebanyak 177 (59,0\%) responden yang menyatakan masih kurang memperoleh perlindungan hukum, dan bahkan terdapat $70(23,3 \%)$ yang memandang tidak pernah memperoleh perlindungan hukum. Dengan demikian dari hasil penelitian tampak bahwa mengenai perlindungan hukum terhadap dokter maupun pasien, masih kurang mendapatkan jaminan perlindungan hukum, sehingga pada akhirnya akan mempengaruhi hubungan antara dokter dengan pasien. Realitas ini, tentunya sangat memprihatinkan karena dapat berakibat pada rendahnya motivasi pasien untuk memperoleh layanan, sebaliknya dokter dalam menjalankan profesinya tidak merasa memiliki kemandirian dan akan sangat terbelenggu dengan kekhawatiran melakukan kesalahan dalam memberikan pelayanan medik.

Memang tidak dapat disangkali dan bahkan menjadi fakta adanya beberapa peristiwa yang dapat dikategorikan sebagai telah terjadi malpraktik di dalam pelayanan medik. Namun kejadian tersebut, tentulah tidak didasarkan atas kesengajaan dokter untuk melakukan malpraktik, tetapi hal itu disebabkan oleh beberapa faktor yang mempengaruhinya.

Adapun faktor-faktor yang mempengaruhi terjadinya malpraktik, disebabkan karena faktor substansi hukum, struktur hukum, pemahaman hukum masyarakat, budaya dan kebiasaan masyarakat, lingkungan masyarakat, sarana dan prasarana pendukung. Untuk lebih jelasnya dikemukakan hasil penelitian berkenaan dengan faktor-faktor yang mempengaruhi terjadinya malpraktik.

\section{a. Substansi Hukum}

Hasil penelitian menunjukkan bahwa dari 300 responden, sebanyak $202(67,3 \%)$ responden yang menyatakan bahwa faktor substansi atau materi undang- undang yang ada mempengaruhi pelaksanaan perlindungan hukum terhadap pasien dandokter yang menjalankan profesi yang di duga melakukan malpraktik medik.Sementara itu, terdapat sebanyak $50(16,7 \%)$ responden yang berpendapat bahwa substansi hukum atau isi undang-undang yang ada kurang mempengaruhi, dan sebanyak $48(16 \%)$ responden justru berpendapat substansi hukum atau isi undang- undang yang ada tidak mempunyai pengaruh terhadap pelaksanaan perlindungan hukum pasien dandokter yang menjalankan profesi yang di duga melakukan malpraktik medik. Realitas ini, mengandung makna bahwa dalam hal terdapat dugaan telah terjadinya malpraktik medik, maka baik pasien maupun dokter pada dasarnya ketentuan perundang-undangan kurang berpengaruh atau bahkan tidak mempunyai pengaruh atas pelaksanaan perlindungan hukum.

\section{b. Faktor Struktur Hukum}

Hasil penelitian menunjukkan bahwa dari 300 responden sebanyak 215 (71,7\%) responden yang berpendapat faktor struktur hukum mempengaruhi pelaksanaan perlindungan hukum terhadap pasien dandokter dalam menjalankan profesi yang di duga melakukan malpraktik medik. Selain itu, terdapat sebanyak $53(17,6 \%)$ responden yang menyatakan bahwa faktor struktur hukum kurang mempengaruhi,sedangkan 32 $(10.7 \%)$ responden justru memandang faktor struktur 
hukum tidak mempunyai pengaruh. Kendatipun pada umumnyaresponden memandang struktur hukum mempunyai pengaruh, namun masih terdapat responden justru berpendapat bahwa struktur hukum kurang atau bahkan tidak mempunyai pengaruh.

\section{c. Faktor Pemahaman Hukum Masyarakat}

Hasil penelitian menunjukkan bahwa dari 300 responden sebanyak 214 (71,3\%) responden yang menyatakan bahwa faktor pemahaman hukum masyarakat mempengaruhi pelaksanaan perlindungan hukum terhadap pasien dandokter yang menjalankan profesi yang di duga melakukan malpraktik medik, dan sebanyak 47 $(15,7 \%)$ responden berpendapat kurang mempengaruhi. Sedangkan yang mengemukakan bahwa faktor pemahaman hukum masyarakat tidak mempunyai pengaruhsebanyak $39(13,0 \%)$ responden. Dengan demikian dari hasil penelitian diperoleh informasi bahwa pada umumnya responden memandang pemahaman hukum masyarakat sangat berpengaruh dalam pelaksanaan perlindungan hukum terhadap pasien dan dokter yang menjalankan profesi yang di duga melakukan malpraktik medik. Karena itu, diperlukan upaya agar pemahaman masyarakat semakin ditingkatkan dalam persoalan hubungan pasien dengan dokter, seperti adanya pelaksanaan sosialisasi hukum yang berkesinambungan.

Dalam kaitanantara pemahaman hukum masyarakat dengan kesadaran hukum akan perlunya perlindungan hukum terhadap pasien dan dokter dalam menjalankan profesinya. Darihasil penelitian tampak bahwa dari 300 responden terdapat sebanyak $200(66,7 \%)$ responden yang menyatakan faktor kesadaran hukum masyarakat mempengaruhi pelaksanaan perlindungan hukum terhadap pasien dandokter yang menjalankan profesi yang di duga melakukan malpraktik medik, dan71 (23,7\%) responden berpendapatkurang berpengaruh,sedangkan $29(9,6 \%)$ responden justru memandang kesadaran hukum masyarakat tidak mempunyai pengaruh dalam pelaksanaan perlindungan hukum terhadap pasien dandokter yang menjalankan profesi yang di duga melakukan malpraktik medik. Realitas ini, dapat diartikan bahwa antara pemahaman hukum masyarakat dengan kesadaran hukum masyarakat mempunyai relevansi yang erat, karena semakin paham masyarakat maka semakin tinggi tingkat kesadaran hukum masyarakat. Karena itu, tidak mengherankan jika dalam penelitian ini menunjukkan bahwa pemahaman hukum masyarakat dan kesadaran hukum masyarakat sangat mempengaruhi pelaksanaan perlindungan hukum terhadap pasien dan dokter yang menjalankan profesi yang di duga melakukan malpraktik medik.

\section{d. Faktor Budaya dan Kebiasaan Masyarakat}

Hasil penelitian menunjukkan bahwa dari 300 responden sebanyak 175 (58,3\%) responden berpendapat bahwa faktor kebiasaan masyarakat mempengaruhi pelaksanaan perlindungan hukum terhadap pasien dandokter yang menjalankan profesi yang di duga melakukan malpraktik medik.Sebaliknyaterdapat sebanyak $69(23,0 \%)$ responden yang menyatakan bahwa faktor kebiasaan masyarakat kurang mempengaruhi dan $56(18,7 \%)$ responden justru memandang tidak mempunyai 
pengaruh. Selain itu, hasil penelitian juga menunjukkan bahwa dari 300 respondensebanyak $185(61,7 \%)$ responden yang menyatakan faktor budaya hukum masyarakat mempengaruhi pelaksanaan perlindungan hukum terhadap pasien dandokter yang menjalankan profesi yang di duga melakukan malpraktik medik. Sebaliknya $72(24 \%)$ responden berpendapat kurang mempengaruhi dan 43 (14,3\%) responden justru memandang tidak mempunyai pengaruh. Dengan demikian, jika dianalisis hubungan antara kebiasaan masyarakat dan budaya hukum masyarakat, tampaknya sangat relevan, karena saling terkait antara satu dengan lainnya. Kebiasaan masyarakat akan membentuk budaya hukum masyarakat dalam pergaulan hidup, terutama dalampelaksanaan perlindungan hukum terhadap pasien dan dokter yang menjalankan profesi yang di duga melakukan malpraktik medik.

\section{e. Faktor Lingkungan Masyarakat}

Dari hasil penelitian menunjukkan bahwa dari 300 responden yang menyatakan faktor lingkungan masyarakat mempengaruhi pelaksanaan perlindungan hukum terhadap pasien dandokter yang menjalankan profesi yang di duga melakukan malpraktik medik, adalah sebanyak $176(58,7 \%)$ responden, sedangkan $84(28 \%)$ responden berpendapat kurang mempengaruhi, dan $40(13,3 \%)$ responden justru memandang tidak mempengaruhi. Kenyataan ini, mengandung arti bahwa kendatipun pada umumnya responden memandang faktor lingkungan masyarakat mempunyai pengaruh, namun tidak dapat disangkali terdapat pula responden yang justru berpendapat faktor lingkungan masyarakat kurang atau tidak mempunyai pengaruh.

\section{f. Faktor Sarana dan Prasarana Pendukung}

Dari hasil penelitian diketahui bahwa dari 300 respondensebanyak 192 (64\%) responden yang menyatakan faktor sarana prasarana pendukung mempengaruhi pelaksanaan perlindungan hukum terhadap pasien dandokter yang menjalankan profesi yang di duga melakukan malpraktik medik.Selanjutnya sebanyak 68 (22,7\%) responden berpendapat kurang mempengaruhi dan40 $(13,3 \%)$ responden memandang faktor sarana prasarana pendukung tidak mempengaruhi pelaksanaan perlindungan hukum terhadap pasien dandokter yang menjalankan profesi yang di duga melakukan malpraktik medik.

Berdasarkan uraian di atas, tampaknya transformasi sosial dalam kaitannya dengan pelaksanaan perlindungan hukum terhadap pasien dandokter yang menjalankan profesi yang di duga melakukan malpraktik medik mempunyai keterkaitan, sehingga dalam realitasnya mempunyai pengaruh terhadap pasien dan dokter dalam hubungan medik. Selain itu, dalam realitasnya pelaksanaan perlindungan hukum terhadap pasien dan dokter yang menjalankan profesi dipengaruhi oleh beberapa faktor, sehingga dapat diketahui penyebab yang paling dominan untuk mengefektifkan perlunya perlindungan hukum baik terhadap pasien maupun kepada dokter dalam menjalankan profesinya.

\section{PENUTUP}

Pengaruh transformasi sosial terhadap hubungan medik antara dokter dan pasien dalam pelayanan kesehatan di Provinsi Sulawesi Selatan, yakni mengalami perubahan, baik dari segi perkembangan ilmu pengetahuan dan teknologi medis maupun dari segi peralatan medis yang semakin canggih. Perlindungan hukum terhadap pasien dan dokter yang 
menjalankan profesi, yang diduga melakukan malpraktek medik menurut peraturan perundang-undangan yang berlaku kurang optimal. Faktor-faktor yang mempengaruhi terjadinya malpraktek medik dan lemahnya perlindungan hukum bagi pasien, adalah faktor substansi hukum, struktur hukum, pemahaman hukum masyarakat, budaya hukum, lingkungan masyarakat, dan faktor sarana dan prasarana.

\section{DAFTAR PUSTAKA}

Anny Isfandyarie, 2005, Malpraktek dan Resiko Medik Dalam Kajian Hukum Pidana, Penerbit Prestasi Pustaka, Jakarta.

Bahder Johan Nasution, 2005, Hukum Kesehatan Pertanggungjawaban Dokter, PT. Rineka Cipta, Jakarta.

Bambang Poernomo, 2005, Hukum Kesehatan, Yogyakarta: Program Pasca Sarjana Magister Manajemen Rumah Sakit UGM, Jogyakarta.

Hasbi Asshiddiqi dkk, 1990, Al-Qur'an dan Terjemahannya,Depag RI, Jakarta.

Safitri Hariyani, 2005, Sengketa Medik, Alternatif Penyelesaian Perselisihan Antara Dokter dengan Pasien, PT. Diadit Media, Jakarta.

Syahrul Machmud, 2012, Penegakan Hukum dan Perlindungan Hukum Bagi Dokter yang diduga Melakukan Medikal Malapraktik, Karya Putra Darwati, Bandung. 